\title{
Elements of Design in Batik Tiga Negeri, Lasem
}

\author{
Nanang Rizali \\ Universitas Sebelas Maret \\ nanangkriya@yahoo.co.id
}

\begin{abstract}
One of the cultural heritages of the archipelago that has been inherited from the ancestors is batik. Based on its history, batik cloth has a philosophical value, symbolic meaning, and an event of identity and social strata and spirituality and the journey of civilization. Batik is a cultural art relic that is different from other cultural relics. Batik tiga negeri (means 'three area countries') is one type of batik that has its own uniqueness that lies in the element of coloring. Batik Tiga Negeri of Lasem is a combination of batik Pekalongan, Solo, and Lasem, It is related to the combination of motifs and colors in the process of making. Lasem is known as Little China that have an acculturation with Javanese tradition.
\end{abstract}

Keywords: batik, tiga negeri, china, acculturation, lasem

\section{INTRODUCTION}

The one of artworks Indonesian culture that admired the world is batik. Batik as traditional fabrics produced through a dip process hurdles. Batikas the work of high culture (adiluhung)in Nusantara is inseparable from a variety of influences, based on historical facts have proven that the most dominant influence is the environment and foreign cultures. Age and irrefutable and the environment can not be separated from the development process of batik to whenever [1].

Batik fabric decoration is made by using candle (malam) as the color barrier material, so that the dye can not penetrate the cloth that was closed candle when dyeing. Batik technique is skill of the Indonesian since centuries ago. In addition, the dyeing raw materials used from plants native to Indonesia, such as indigo, indigo, and the indigo. Batik activities especially in Java growing and developing very rapidly and the region contribute to type and batik decoration richly colored, complex, and subtle. The different in type of batik Solo and Yogyakarta with batik northern coast of Java show Indonesian batik has a variety. For example, batik made in the area of Cirebon, Pekalongan, Lasem, Tuban, and Madura, which has the characteristics of each region.

\section{METHODS}

The subject of this research is about tiga negeri batik (means batik from three areas). The goal is to describe the element that construct the motif. The location is in
Kecamatan Lasem, Kabupaten Blora, Central Java. The sources of data are informants, avent, and batik cloth about batik tga negeri. So it is a kind of analytic and descriptive research.

\section{The Touch of Local Cultural Traditions with The Value of China}

Indonesian islands located in the middle of the traffic of trade and foreign culture, so it becomes a place for many nations. In addition to trade various activities carried out by the settlers, such as the further spread of religion even family relationships and settle in Indonesia. Since the arrival of foreign nations, where Indonesia became known, including the Chinese nation began to establish trade relations. After the trade contacts also introduces the culture and customs, thus adding to the repertoire repertory batik decoration in the archipelago. As an example pattern on ceramic Chinese mythology has become a new concept of creative works of art (visual) Nusantara.

Contacts in the relationship with nations outside the region also occurred interplay in various fields. The presence of other nations to the archipelago have affected also local art, especially in coastal areas and ports. Culture and art from the outside and then absorbed, filtered, and combined with the uniqueness, beauty and personality of his own. According to sources, the Chinese culture is expected to enter into the archipelago since the onset of masehi, while simultaneously the influx of Indian culture entered Hinduism masehi 150 [2]. In the northern coastal areas of Java contacts not only with overseas, but also the relationship between the archipelago. For example, with the famous Madurese as seamen and often stop in the port of Lasem, Pekalongan and Indramayu, so that the batik cloth there are similarities tone.

In the process of acculturation appears that Chinese migrants to adopt local cultural traditions, Java in terms of batik. Their harmonious contiguity between Chinese culture with the cultural traditions of coastal Java Lasem been growing between the two nations already established long ago. The Chinese adopted batik to meet spiritual ceremonial purposes, such as tablecloths altar painted with animal shapes dragon, phoenix or swastika, and Banji. Batik fabric used for religious among towie (altar cloth), muklie (linen tablecloths), and the altar wall hangings [1]. The process of acculturation two cultures has created a balance between the cultural traditions of north coast of Java and the Chinese culture. Contiguity 
their culture values harmony philosophy has produced a mutually beneficial cooperation and avoid inter-ethnic conflict.

Lasem is one of northern coastal areas in Java under the influence and ideology of China, resulting in a harmonious art form of batik art. Various literature states that Lasem batik as one of the variants of classical batik with distinctive patterns and styles. Batik Lasem developments closely associated with the arrival of Admiral Cheng Ho in 1413. The text was reported that the crew and Pahawang Tzeng Ho from China named Bi Nang Un and his wife $\mathrm{Na} \mathrm{Li} \mathrm{Ni}$ originating from the Champa chose to live in Bonang, Lasem. After seeing the natural beauty of Java, then $\mathrm{Na}$ Li Ni start motivated batik phoenix, Liong, Chrysanthemum Flowers, Banji with red color as typical of China. Some motifs are then known to be characteristic and unique batik Lasem (Laseman). Thus Lasem batik decoration traditional conservative character means that the motif generated a tradition of Javanese culture creations influenced by the ancestral culture and legends of China.

Acculturation tradition of Javanese culture with Chinese culture, according to anthropological studies included in the framework of the theory of contact.According to the understanding of social processes of acculturation is a certain culture are confronted with elements of other cultures, which gradually led to the missing of his own personality [5]. In some areas of Indonesia there has been an acculturation process that enriches the existing culture. In the case of the city Lasem, ideology region has unique characteristics as an alternative ideology (China) alongside a coastal Javanese ideology.

\section{Blended Design of Elements in Batik Tiga negeri}

As a cultural tradition of batik, batik Lasem has become a leadingindustrial product areas potentially, because it has the feel of beauty, especially in red color. Lasem greatness can not be separated by the name of Cheng Ho, known as Sam Po Kong which means three Buddhist heritage. Laksamana Zheng He sailed the ocean to West Indies, sent by the emperor Zhua in Ming dynasty in the early 15 th century. Then finally stopped at the northern coast of Java around Lasem and there was a relationship in various fields. In development occurs in harmony contiguity between the two cultures which foster mutual influences with a distinctive character.

Visually embodiment batikLasem has progressed, so has three categories of sustainability. The third type of batik lasem known as classical batik (the people), batik and batik laseman contemporary, which is based on the motifs and colors as well as manufacturing techniques. Watu pecah motif (brolen stones) describes the condition of the Lasem community at that time, which imposed hard labor to break the stone for road construction. Batik Laseman is batik motives like unique animals like China Liong, Can Lok birds, butterflies, peacocks, and the other. The shape of these motives beliefs and mythology adopted from China combined with classic batik Lasem without losing the identity and trademark. Laseman Batik then evolved into what is called Contemporary Lasem batik that is influenced by fashion trends and fashion today.

Previous batik types (Classical and Laseman) retained as the rich variety of Batik Lasem, namely red color and batik techniques he wrote. Some types of contemporary batik developed today include Tiga negeri motif, Early Evening, Day and Night, Tumpal Clorat, and others. Function use of this type of batik cloth increasingly diverse abreast of fashion / fashion, so it's compatible with the needs of contemporary textiles.

Historically, the uniqueness of the Tiga negeri Lasem batik lies in the dyeing is done in three different locations. Third batik city in question is Lasem (Rembang), Solo and Pekalongan have a very far distance to process batik cloth Tiga negeri.

Tiga Negeri batik was not apart of the history of the Dutch colonial period, which lie within the region third Lasem, Solo and Pekalongan mempunyai own autonomy called 'country'. This is the name of the Tiga negeri batik became known and popular in the archipelago.

Basically motif Tiga negeri Lasem influenced by three elements of design patterns, such as the influence of Chinese culture, such as the shape phoenix, Phoenix were considered to have a legend. Then the effect of Solo-Yogyakarta batik style, the classic batik art center which is famous for its philosophical value, such as Parang, Kawung, Sido Mukti, and so forth. Furthermore, also influenced by the tastes of Northern coasts of Java batik as Pekalongan, Cirebon, Lasem known circuitry using bright colors, such as red, blue, yellow, and others. Batik Tiga negeri progressed from the early 1900s, which was adopted in part by a family dynasty Tjoa Solo batik from China. Around 1910 batik expertise passed down to his son as a family batik business Tjoa.

Some batik Tiga negeri of which is the motive morning-afternoon Coastal, Sido Mukti Tjoa variation Alas-grounds. Type of morning-afternoon Coastal batik is a piece of cloth that has two sides of different motives.

In general, Sido Mukti Batik Solo, although the name means the same, Sido means so or does not fail, while Mukti means happy and quiet life for the wearer. Jam exists batik Luhur Sido, which literally means the same as Sido Mukti, which Sido means so or not undo and noble means respectable. In the days of ancient royal batik patterned or Sido Luhur Sido Mukti should not be used by most people, especially dipakai by the nobility.

One type of batik Three other land that is, the motive Alas-grounds as well as Sido Mukti motif known in Solo. Alas mean forest which depicts the life of the forest full of flora and fauna. This gives the impression of a luxury full and almost all fabric surfaces, almost all of the production of batik Tiga negeri Tjoa version patterned like this. As batik patterns in the northern coastal areas of Java which is produced by the batik descendants of Dutch and Chinese. Generally influenced by local cultural traditions, local religious and immigrant cultures, thereby generating a rich blend of design elements and luxury at the edges of the fabric. Process of batik goes a 
long time, so it is relatively expensive and is owned by the upper middle class. Thus, batik is only used for certain official events, given the complexity of motifs and color appearance.

At batik Tiga negeri appears the influence of China as red as Chinese ethnic characteristics and also popularize motifsphoenix, dragon and others. The Dutch nation to introduce many shades of flowers, such as tulips buketan or that there are natural forms of other objects including blue. Although eventually the red color that dominates in batik Tiga negeri, due to the Chinese, red symbolizes luck and happiness according to the fire, while the red color considered Lasem community through its local batik color Classic. The name of Tiga negeri batik is closely related to the process of fabricating and dyeing cloth done in three different batik centers, namely Lasem, Pekalongan, and Solo which was once considered a country.

As a result of interplay between the two cultures, then there are motifs of flora / flowers are not much different with batik motifs typical of Dutch descent. Only for the people of Chinese descent any motifs of flora and fauna is always associated with symbolic meanings like grandeur, prosperity, gentleness, and the nature of Yin. For the Javanese-any particular motive as it is considered as a repellent reinforcements, while fish symbolizes prosperity abound. This is due to the trust, tradition legend hereditary and poured in batik.

\section{CONCLUSION}

Since the Chinese presence in various ethnic groups, especially in Lasem has happened acculturation, that is, when a high Javanese culture faced with the Chinese cultural tradition values. Javanese cultural traditions were introduced to a new view of the creativity in the creation of batik. This is evident in the concept behind the creation of batik Laseman accommodate local cultural traditions. Some of the findings in Lasem batik motive is a blend of design elements that express the values of local traditions with Chinese cultural values, such as the batik Tiga negeri. Tiga negeri motif pattern contained atmosphere of society living in harmony side by side with the settlers. As a manifestation of the union of two cultures that characterize the batik.

Batik Three countries began to develop in the early 1900s who pioneered one of them by a family dynasty Tjoa batik from Solo. The implied message of this batik is the life of a society, nation, and state, there are times when faced with different ethnicities culture. Batik Tiga negeri provided evidence that ethnic and cultural differences can walk together and inspire each other in the work. In addition to their contiguity cultural tradition values also occurs a fusion of the elements of the design. Lasem batik motifs in progress can be made can be used as a model of harmony in China and Java acculturation which is reflected in the embodiment of batik.

\section{REFERENCES}

[1] Doellah, H. Santosa, 2001, Batik: TheImpact of Time and Environment, Danar Hadi: Surakarta.

[2] Djoemena, Nian, 1990, Ungkapan Sehelai Batik, Djambatan: Jakarta.

[3] Djoemena, Nian,, 1990, Batik dan Mitra, [1] Djambatan: Jakarta.

[4] Kontjaraningrat, 1983 PengantarIlmuAntropologi, AksaraBaru: Jakarta.

[5] Rizali, Nanang, 2014, Nafas Islami dalam Batik Nusantara, Uns Press: Surakarta. 